\title{
Impoverishment of the Poor and Derogation of Human Rights During the Covid-19 Pandemic in Indonesia: Testing the Emergency Measure and Siracusa Principles in Large-Scale Social Restriction
}

\author{
Manotar Tampubolon ${ }^{1,2}$ (D) \\ Accepted: 7 April 2021 / Published online: 13 July 2021 \\ (c) The Author(s), under exclusive licence to Springer Nature Switzerland AG 2021
}

\begin{abstract}
This study examines human rights restrictions in the Large-Scale Social Restrictions (or PSBB) during the Covid-19 outbreak in Indonesia that do not follow the Siracusa Principles emergency measure and limitation clause. PSBB resulted in a prolonged human rights crisis due to ineffective policies, manipulated data, and inadequate medical equipment. The author discusses the impact of Large-Scale Social Restrictions on socio-economic and socio-political rights and the government's failure to overcome the Covid-19 outbreak with an interdisciplinary perspective. Findings from studies on the number of Covid-19 cases contracted and the high mortality rate are also presented. This study notes the consequences and the relationship between the ineffectiveness of Large-Scale Social Restrictions and human misery.
\end{abstract}

Keywords Restrictions of human rights · Emergency measure $\cdot$ Siracusa Principles $\cdot$ Proportionality $\cdot$ Violations $\cdot$ Human rights misery

\section{Background}

The coronavirus (Covid-19) outbreak hit most of the world's population (UN 2020), including Indonesia. It is not only a national emergency: according to the World Health Organization (WHO 2020a), it meets the criteria of a Public Health Emergency of International Concern (PHEIC, see WHO 2020a). In June 2020, the WHO announced 28,233 confirmed Covid-19 cases, 1,698 death cases and 8,406 recovered cases globally (WHO Indonesia 2020). The number of people affected by Covid-19 places Indonesia in a position with the world's highest mortality rate (Worldometer 2020). The number was projected to increase if there were no early efforts to overcome its transmission.

Spain, Iran, Italy, Denmark, Israel, and Germany among countries implemented a more relaxed lockdown policy, on the other hand, China implemented the most extensive and most stringent mass quarantine in human history (Business Insider 2020). However, the Indonesian Government

Manotar Tampubolon

justitie234@gmail.com; manotar.tampubolon@uki.ac.id

1 Faculty of Law, Christian University of Indonesia, Jakarta, Indonesia

2 Universiti Teknologi MARA, Shah Alam, Selangor, Malaysia believed that the most effective way to stop the outbreak of Covid-19 was not by implementing a lockdown. Instead, the Government declared a health emergency through Law No. 21 year 2020 on Large-Scale Social Restriction (known as Pembatasan Sosial Berskala Besar, or PSBB). The LargeScale Social Restrictions (hereafter PSBB Regulation, or PSBB) is a policy restricting human movement and encouraging social distancing to stop the spread of Covid-19 (Ivanka 2020).

Although Indonesia has ratified eight human rights covenants that guarantee human rights protection (Ministry of Foreign Affairs 2019), the country has a set of laws allowing human rights restriction in a state emergency. The 1945 Indonesian Constitution (UUD 1945), Law No. 39 of 199 on Human Rights, Law No. 6 of 2018 on Health Quarantine (UUKK), Presidential Decree (KEPRES) No. 11 of 2020 on Determination of the Public Health Emergency Corona Virus Disease 2019 (Covid-19) and the Government Regulation No. 21 of 2020 on Large-Scale Social Restrictions in the Context of Accelerating Handling of Corona Virus Disease 2019 (Covid-19) respectively. The limitation of human rights in emergency conditions is permissible as long as it qualifies the requirements of legality, necessity and proportionality. It must also be non-discriminatory (United Nations Human Rights Office of the High Commissioner 2020) and meet 
the conditions set by Siracusa Principles (United Nations Commission on Human Rights 1984).

However, a problem arises when restrictions on the right to move (intended to reduce the spread of Covid-19) are implemented but are not in balance with the result, and even causing detrimental consequences to other human rights. In this situation, a second emergency phase begins and possibly another. In Indonesia's history, infectious disease outbreaks occurred with quarantine, such as the Bubonic Plague in 1911, but could not ultimately be solved (Luwis 2008). Due to government neglect and inadequate health facilities, the result was thousands of victims from civil society, medical circles, doctors and nurses (Luwis 2008).

In the context of Covid-19, the Indonesian Government seems to be more concerned with avoiding an economic recession than saving lives (Jaffrey 2020). This has resulted in the priority to control the pandemic by PSBB rather than lockdown. Additionally, the lack of government oversight, people's ignorance due to the absence of restrictive measurement, and government ineptitude (Dwi 2020; Jaffrey 2020) make this control miserable. The measurement control of the Covid-19 outbreak leads to other human rights crises (Solahuddin 2020), not only rights to life but also socio-politic and socio-economic issues such as limiting the right to worship, job losses, access to education, child malnutrition, child poverty crises and maternal undernutrition (UNICEF 2020).

Based on the above facts, this study focuses on this new problem. The question we are trying to answer becomes twofold. Do the PSBB Regulations governing human rights restriction during Covid-19 meet emergency measurements and the Siracusa Principles' provisions? Second, what are the impacts on socio-politic and socio-economic rights? The author's answer to the first question is no. Moreover, to the second, it is argued that the ineffectiveness of the PSBB Regulations leads to human rights misery and an imbalance between health crisis and human misery.

This study consists of five parts. 'Background' contextualizes the topic and issues raised. 'Literature Review' reviews the literature, consisting of a previous study on human rights restriction during a health emergency. 'Study Method' outlines the methodology of this study. Indonesia's response to Covid-19 analyses the PSBB Regulations, beginning with their legal basis and the debate regarding derogation, which illustrates how enforcement of the regulation leads to compromised human rights. The impact of PSBB Regulation on a different set of freedoms is identified. 'The Emergency Measure and Siracusa Principles in Great Scale Social Restriction' examines the emergency measure and Siracusa Principles in GreatScale Social Restriction (PSBB). The 'Conclusions' section shows how the application of regulation in PSBB Regulation is disproportionate with emergency measures and Siracusa
Principles. It is asserted that the PSBB Regulation was not the right solution to reduce the spread of the Covid-19 pandemic because this caused a prolonged human rights crisis.

\section{Literature Review}

Restriction of human rights during emergencies has attracted the attention of earlier scholars. Some scholars argue that the limitation of human rights in the Constitution must correspond with proportional standards (Osiatynski 2009; Parek 2009; Webber 2009; Klatt and Meister 2012; Rosenfeld and Sajó 2012). Such limitations must also meet emergency measurements (United Nations Human Rights Office of the High Commissioner 2020). There must also be a relationship between agreed goals of the restrictions to be agreed on and the minimum rights or freedoms to be infringed on, with a balanced outcome (Huscroft et al. 2014). Importantly, these restrictions must meet the requirements of legality, necessity and proportionality, and be non-discriminatory (United Nations Human Rights Office of the High Commissioner 2020).

Meanwhile, the concept of proportionality itself differs between writers. Huscroft et al. (2014, p. 4) mention both proportionality and balance and proportionality between means and ends. State/government policies that restrict human rights must be conducted with a legitimate goal in mind (Christoffersen 2009), with the main conditions for restriction approved and completed according to their designation goal (Smith 2012, p. 186).

Also, the rules determining the restriction and derogation of human rights in state emergency conditions must meet the Siracusa Principles (American Association for the International Commission of Jurists 1984). The minimum standard must be met, including that they are: (1) provided for and carried out by the law, (2) directed towards a legitimate aim, (3) strictly necessary in a democratic society to meet the aim, (4) the least intrusive and restrictive available to reach the aim, (5) based on scientific evidence and neither arbitrary nor discriminatory in application, and (6) of limited duration, respectful of human dignity, and subject to review (United Nations Commission on Human Rights 1984). Human rights derogation during health emergency general interpretive principles relating to the justification of limitations (Abiola 2011):

1. No limitations or grounds for applying them to rights guaranteed by the Covenant are permitted other than those contained in the terms of the Covenant itself

2. The scope of a limitation referred to in the Covenant shall not be interpreted to so as to jeopardize the essence of the right concerned 
3. All limitation clauses shall be interpreted strictly and in favor of the rights at issue

4. All limitation clauses shall be interpreted in the light and context of the particular right concerned

5. All limitations on a right recognized by the Covenant shall be provided for by the law and be compatible with the objects and purpose of the Covenant

6. No limitation referred to in the Covenant shall be applied for any purpose other than that for which it has been prescribed

7. No limitation shall be applied in an arbitrary manner

8. Every limitation imposed shall be subject to the possibility of challenge to and remedy against its abusive application

9. No limitation on a right recognized by the Covenant shall discriminate contrary to Article 2, paragraph 1

1. Whenever a limitation is required in the terms of the Covenant to be "necessary", this term implies that the limitation:

(a) Is based on one of the grounds justifying limitations recognized by the relevant article of the Covenant

(b) Responds to a pressing public or social need

(c) Pursues a legitimate aim

(d) Is proportionate to that aim

(e) Any assessment as to the necessity of a limitation should be made on objective considerations.

(f) In applying a limitation, a State shall use no more restrictive means than are required for achievement of the purpose of the limitation

(g) The burden of justifying a limitation on a right guaranteed under the Covenant lies with the State

(h) The requirement expressed in article 12 of the Covenant, that any restrictions be consistent with other rights recognized in the Covenant, is implicit in limitations to the other rights recognized in the Covenant

(i) The limitation clauses of the Covenant shall not be interpreted to restrict the exercise of any human rights protected to a greater extent by other international obligations binding on the State

Studies also mention the critical role of social workers and health care facilities in such an emergency. Social workers have been designated essential workers throughout the pandemic (British Association of Social Workers 2020). Professional service provision by social workers should become mandatory (Brinkerhoff 2014). Social workers must prevent social disturbances from bizarre conspiracy claims, rumours and fears, or outright neglect by the authorities (Amadasun 2020).
A recent study suggests that the implementation of Siracusa Principles on Health Emergency due to the Covid-19 pandemic are difficult to operationalize in public health crises because these principles are meant to apply broadly to all public emergencies (Sun 2020). Other scholars such as Ivanka (2020), Andriani (2020), Syafri et al. (2020), Suraya et al. (2020), Mahmud et al. (2020) have examined PSBB in terms of its function and validity. Still, none of these authors have examined the requirements PSBB whether under the standards set by Siracusa Principles and Emergency Measures. The research differs from previous research in terms of the focus of research - to determine the elements specified in the Siracusa Principles and Emergency Measure in the PSBB and the impact of the PSBB on human rights.

\section{Study Method}

This transdisciplinary study tries to overcome the mismatch between academia's knowledge and solving societal problems (Leavy 2011). It applies social sciences, legal studies, health and social work approaches to overcome issues. This study looks at various theories related to the fulfillment of human rights in Indonesia during the Covid-19 pandemic. The conceptual approach is used to see various views and legal doctrines in examining the implementation of the fulfillment of human rights in Indonesia in the health emergency situation of the Covid-19 Pandemic.

The author uses related national legal, social sciences, and health literature in full context, including international legal norms adopted by the regulation. Primary sources such as PSBB and Siracusa Principles and secondary data sources such as legal instruments, both national and international, books and international organizations' databases were necessary to analyse the problem. Such a combination of approaches is desirable, as it provides a strong foundation from which to explore the existing problems and find more creative and liberating solutions to these problems.

This study departs from the PSBB Regulation that has not fulfilled all the international restriction clauses set by Siracusa Principles to change the existing law and its implementation difficulties. These facts cannot be studied better without sociological investigation (Singh 2006). Thematic analysis is beneficial for meeting the purpose of a research paper with help of themes developed based on research objectives. The thematic analysis focuses on answering research questions: Do the PSBB Regulations governing human rights restriction during Covid-19 meet emergency measurements and the Siracusa Principles' provisions? Second, what are the impacts on socio-politic and socioeconomic rights? 
The limitations of the study are in two areas. The first area is that the study focused specifically on whether the PSBB meets the standards specified by the Siracusa principles and Emergency measure, so there is no information provided if a similar situation that PSBB met with any other international standard. The second limitation is that the researcher chose a qualitative research method to review COVID-19 regulations, which means that a much more comprehensive view of the research topic based on primary quantitative analysis is not conceivable.

\section{Indonesia's Response to Covid-19}

\section{Why Large-Scale Social Restrictions (Pembatasan Sosial Berskala Besar or PSBB)?}

The Large-Scale Social Restrictions or Pembatasan Sosial Berskala Besar (PSBB) is a limitation of certain activities of residents in an area suspected of being infected with a disease and/or contaminated in such a way as to prevent the possibility of spreading the disease or contamination. It is part of the Public Health Emergency response. The scope of the PSBB includes: school and work vacations, restrictions on religious activities, restrictions on activities in public places or facilities (Government Regulation No. 1 Year 2020). The Indonesian government chose the PSBB policy to prevent the spread of Covid-19 and did not implement a lockdown as was adopted by other countries because the latter is not known in Indonesian legal system.

However, the initial response to the health emergency was delayed due to the myth that Indonesia would be immune to Covid-19 (Pramudiarja 2020; John Hopkins Bloomberg School of Public Health 2020). High temperatures and humidity characterise Indonesia's location and the virus was assumed not to be able to live long, supporting the myth (Pujianto 2020). However, the myth was refuted by the discovery of the virus in the third week of January 2020 by experts from the Faculty of Public Health, University of Indonesia. The Minister of Health also supported the myth of immunity in his statement, as cited by Detik News, arguing that Indonesia was immune to Covid-19 because of prayer (Pramudiarja 2020).

This denial of the spread of the Covid-19 pandemic, backed up by a lack of reliable data, led to a late imposition of a health emergency by the Joko Widodo government (The Jakarta Post 2020c). However, 2.5 months before the media Minister of Health statement, the WHO (2020b) had detected the Covid-19 spread in Indonesia. They urged the country to declare a national health emergency (The Jakarta Post 2020b).

In such situation, the policy allows the state to limit freedom of movement because the Covid-19 outbreak in Indonesia spread relatively fast (Djalante et al. 2020). A prerequisite of the policy (see Article 4, paragraph 3) is that the Central and Local Governments and related agencies must fulfil citizens' basic needs, including:

1. The right to get essential health services according to medical needs.

2. The right to get food and other daily needs.

3. The right to receive the same treatment in administering Health Quarantine.

4. The Government has the responsibility to meet the basic needs of people's lives, animal feed, and its implementation involves the Central Government, Regional Governments and related parties.

5. Every person who comes from a State or area of a Public Health Emergency is entitled to receive services from the Health Quarantine Officer which includes: (1) Screening, (2) Health Alert Card, (3) Information on how to prevent and treat an outbreak, (4) Taking specimens/samples, (5) Referral, and (6) Isolation.

6. The right to receive compensation due to the loss of assets caused by the emergency.

7. The right to obtain information on Health Quarantine to prevent and eradicate the entry and exit of events or risk factors that can cause a Public Health Emergency.

Several arguments have been put forward for the country's preference to opt for the PSBB rather than a lockdown. First, President Joko Widodo considered the PSBB to be the most rational choice among several policy options for accelerating the handling of Covid-19 (Sulistyawati 2020). The PSBB considered Indonesia's characteristics with islands scattered across the archipelago, population, and demographics and how to meet the 'basic needs' of a hundred million of the population (Sulistyawati 2020). Second, if the Government implemented a lockdown, the central government would be responsible for people's basic needs and livestock food in the quarantine (Article 55 Law No. 6 of 2018). Third, under PSBB policy, people can still work because the requirements are to merely adopt social distancing: school and work vacations, restrictions on religious activities and restrictions on activities in public places. Lastly, this was not a pro-poor policy, but it was the Government policy to tighten its belt and maintain economic stability and avoid meeting 267 million people's basic needs. Indonesia's Minister of Finance must spend IDR 255.1 trillion or USD. 1.774 million on the 2020 State Budget (APBN) for handling the Covid-19 pandemic. The budget includes health sector funding of IDR 75 trillion or USD 5,217 million, Social Safety Net investment of IDR 110 trillion or USD 7. 652 million and business support of IDR 70.1 trillion or USD 4.870 million (Ministry of Finance 2020a).

There is no doubt that the PSBB Regulation is not based on full considerations of factors including epidemiological 
aspects, the magnitude of threats, the effectiveness of measures implemented, resource support, and operational, technical, economic, social, cultural and security issues (Disantara 2020). Saving people's lives moves the country from balancing the economy and health towards a strategy that has yielded worse outcomes for both. This country is really in a tight squeeze. On the one hand, the government has no choice and must implement the PSBB to protect the safety of its people from the Covid-19 pandemic, and at the same time it must protect the people's economy. For this reason, the government should give full freedom to the people to carry out mobility and activities. But on the other hand, the government must also be able to maintain and protect the life of its people.

Whatever the government rationale for choosing the PSBB as their approach to save millions of people's lives from the pandemic, it was too late and ineffective. While the restrictions on people's rights were aimed at overcoming the health crisis, they have instead resulted in prolonged suffering. For example, the number of people below the poverty line increased by 12 million (Suryahadi et al. 2020). The economy has become sluggish and the fiscal deficit widens without economic growth (The World Bank 2020). There were 2,084,539 workers from 116,370 companies laid off and terminated (Indonesian Institute of Sciences 'LIPI' 2020). The decline in business activity as people isolated themselves at home led to a dramatic drop in economic growth of -3.8\% (Ministry of Finance 2020b). Government spending must occur to meet the community's basic needs during the lockdown period (Article 1 Government Regulation Number 21 of 2020). A fatal impact occurs when more people become infected and die because of the virus and ineffective use of protective measures (Jaffrey 2020). Social workers and doctors are the victims of a lack of personal protective equipment (PPE), stigma and discrimination (Amnesty International 2020).

\section{Ineffective Policy and Misery to Humanity}

Indonesia's Covid-19 deaths have soared and have been the highest in Southeast Asia. As of 3 March 2021, the official number of confirmed cases reached $1,353,834$ people and 36,721 deaths (World Health Organisation-Indonesia 2021a). As of May 26, the Indonesian government reported 1,791,221 (5034 new) confirmed COVID-19 cases, 49,771 (144 new) deaths, and 1,645,263 recovered cases (World Health Organisation-Indonesia 2021b). The country has taken extensive emergency health measures to control the national spread of Covid-19 and even prohibited the spread of news related to Covid-19 on social media (Ministry of Communication and Informatics 2020). However, the country has been practising a policy that has not achieved its goal and is causing misery to humanity within Indonesia.

While these efforts seek to save people's lives, they bring about economic disaster as people living below the poverty line are increasingly languishing. People are afraid to make a living out of fear of being infected-there are increasing numbers of people whose living standards are in decline. Badan Pusat Statistik (2020) (The Central Statistic Agency 2020) found that the number of poor people had grown to 2.76 million as a result of Covid-19 pandemic. Consequently, many people are unable to meet the basic needs of their families. Children are the most significant victims of this economic turmoil. Besides malnutrition, they cannot go to school and cannot afford to buy internet credit to attend virtual classes. UNICEF (2020) recorded more than 60 million students in Indonesia are temporarily out of school due to Covid-19, affecting their future in an unprecedented way.

Instead of saving human lives, this pro-poor policy causes calamity for thousands of human lives. A recent independent survey by the Asia Pacific Foundation of Canada (2020) noted that the mortality rate following the implementation of the PSBB was much higher than before. The survey notes that the fatality rate is 8.1, the highest in the region (Rodriguez 2020). Late anticipation of the Covid-19 outbreak and inadequate health care facilities cause fatalities, which has resulted in the death rate continuing to rise.

Healthcare workers who are at the front line do help to prevent the spread of Covid-19 but the lack of equipment and facilities is proving fatal to them. Indonesia's health workers do not function optimally because of the lack of available medical equipment or PPE (WHO 2020c). As a result, the number of health care worker victims has increased with 2.4 percent of the death rate (CNN Indonesia 2020). At the end of June 2020, the Indonesian Doctors Association announced that 56 doctors died due to Covid-19. The Indonesian National Nurses Association (PPNI) has also been reported by Tarigan and Milko (2020) as stating that Indonesian nurses' mortality is one of the highest globally, reaching $6 \%$ of the total deaths. On 23 June 2020, Indonesia had seen 30 nurses die, 129 test positive for Covid-19, 717 with People Under Supervision, and 64 in Patients Under Supervision (PDP) status.

Other issues include inadequate health service facilities, such as hospitals and PPE (ADP). Fatalities will increase because average hospital facilities do not have Covid-19 and vaccine facilities. Until the PSBB came into force, only 132 referral hospitals could treat Covid-19 patients across the country (Marchelin 2020). Without health care availability, in terms of the number of hospitals, intensive care beds and accessibility, free versus paid would also affect mortality (Allard and Widianto 2020).

Moreover, public distrust due to lack of transparency of information leads to less compliance with state policies (Mabillard and Pasquier 2015) such as health protocols, social distancing, PPE use and practising hygiene. The Government's lack of openness regarding the budget and information about Covid-19 contribute to this distrust. In the Transparency International Report (2020), several 
societal elements have urged the Government to be transparent regarding the Covid-19 response funds due to different figures submitted to the public from time to time. The Government's closeness regarding the use of the Covid-19 budget certainly increases the chances of budget misuse and criminal acts of corruption.

Following Presidential Instruction Number 4 of 2020, the President ordered all ministries and agencies to refocus and prioritise budget reallocation for handling Covid-19. Government Regulation No.1 / 2020, Article 27 clearly states that all actions and uses of the budget to stabilise the financial system during a pandemic does not comprise civil or criminal matters.

Based on this rule, the costs for handling Covid-19 cannot be counted as a state loss because the budget issued is part of the economic cost to save the economy from the crisis at both national and regional levels. It is no surprise that those in need did not enjoy many of the funds for Covid-19 because of corruption. The Special Task Force's findings for Supervision of Covid-19 Funds at the National Police Headquarters noted that there were 102 cases of suspected misappropriation of social assistance funds for handling Covid-19 throughout Indonesia (Antara 2020).

Discrimination and stigmatisation are common in the country during Covid-19. Discrimination and stigma happen to sufferers at the hospital and during the burial of Covid-19 victims' corpses. For example, in several regions of Indonesia, the refusal to bury the bodies of Covid-19 victims because it will transmit the disease to the community is a form of stigmatisation (Antara 2020).

Lastly, the government's response to the Covid-19 pandemic affects the population because it can pose risks to human rights, including the rights of medical workers, transparency of information and freedom of expression, workers' rights, and social security (Jaffrey 2020). During the Large-Scale Social Restriction (PSBB) implementation, the government was deemed not to protect workers' rights. Termination of large-scale employment or wages reduction because companies have lost money with a declining economy because of the Covid-19 pandemic has gone unnoticed.

Another example is the fulfillment of basic needs or assistance from the government for affected communities which is only guaranteed during the PSBB. Law Number 24 of 2007 concerning Disaster Management which consideration in the Governor's formation Regulation, states that people affected by disasters may receive assistance from the government in a disaster.

The police have also violated the rights of traders by simply dismissing informal traders' businesses. However, when asked why they are still doing business during this pandemic, they stated they will not have money to eat if they did not work (Wiratraman 2020).

\section{The Emergency Measure and Siracusa Principles in Great Scale Social Restriction}

The question that arises is whether the actions outlined above meet the emergency measure and limitation clause in the Siracusa Principles.

\section{State Emergency}

The fundamental goal of the PSBB Regulation, which came into force on 30 March 2020, is to cut the Covid-19 pandemic spread because it threatens the country's public health. Indonesia is not immune, and the war against the pandemic to save the nation's life from a state health emergency begins by restricting freedom of movement. Regarding the situation, a state emergency was proclaimed, namely: the spread of Corona Virus Disease 2019 (Covid-19) with the number of cases and the number of deaths have increased and expanded across regions and the country and affected the political, economic, social, cultural, defence and security lives, as well as community welfare in Indonesia (Cabinet Secretariat of the Republic Indonesia 2020). The Presidential Decree (PSBB Regulation No. 21 of 2020) stated that Covid-19 is a 'Non-Natural National Disaster' (The Jakarta Post 2020a). One of this decree's purposes is to fulfil the state's positive duties to protect public life. The imposition of a state of emergency is essential for saving the right to life from dangerous diseases, such as in the Covid-19 pandemic.

The decree imposing restrictions on freedom of movement meets the standard of the principles. There were permissible violations of human rights by the state while the regulation came into force, including:

1. The school and university closure is a deprivation of freedom to get a proper education as stipulated in Article 31 paragraph (1) of the 1945 Constitution: 'Every citizen has the right to get an education'. This closure is also a violation of the child's human rights to get an education.

2. The workplace closure is a violation of Article 27 paragraph (2) of the 1945 Constitution of the Republic of Indonesia, stating that 'Every citizen has the right to work and a decent living for humanity'. The closure of companies' operations also falls into this category.

3. Restriction of religious activities is a deprivation of the right to freedom of worship as regulated in Article $28 \mathrm{E}$ paragraph 1 of the 1945 Constitution of the Republic of Indonesia.

4. Restriction of activities in public places or facilities and restrictions on social and cultural activities violate Article 28 of the 1945 Constitution stating that: 'Freedom 
of association and assembly, expressing thoughts with orally and in writing and so forth stipulated by Law'.

5. Restriction of transportation mode is a violation of Article 27 paragraph (1) and (2) of Law No. 39 of 1999 on Human Rights.

6. Restriction of other activities specifically related to the defence and security aspects is a violation of Article 29 and Article 30 of Law No. 39 of 1999 on Human Rights.

However, Article 4 of the ICCPR only recommends favourable assignments to states to intervene where there is a real or direct risk to life so that the state can derogate certain rights. The Covid-19 pandemic situation requires more scientific evidence to show that the PSBB Regulation is needed to reduce its spread.

\section{Threat to the Life of the Nation}

To consider whether a public emergency that threatens the nation's life as the basis of enacted regulation to derogate human rights, it is necessary to look at whether the Covid-19 pandemic is a real 'threat to the life of the nation'. Consideration of PSBB mentions that the regulation's purpose was to cut the spread of Covid-19. However, it did not record valid evidence showing that the threat of the Covid-19 pandemic was a threat to the life of the nation'. One reason is that the country's testing systems were inadequate and even claimed to be the worst in the world (Firdaus and Racthliffe 2020).

It was still doubtful whether the death of 122 people (as of 30 March 2020 or before PSBB came into force) met the standard classified as a threat to the nation's life from the health sector indicator. In contrast, some areas of Indonesia had yet to confirm the Covid-19 outbreak, such as the Gorontalo province of North Sulawesi (Kompas 9 April 2020). Besides, the Government's mortality rate as the basis to enact PSBB Regulation may be engineered data. For instance, the Indonesian Doctors Association (IDI) Chairman said the number of deaths due to Covid-19 was double the Government's official data (Intan 2020).

It becomes questionable whether the PSBB Regulation ground is dubious because it results from a low-level testing system. Does it meet the standard to categorise a public emergency that threatens the nation? However, to measure whether the spread of Covid-19 as a health emergency that threatens national life must qualify the benchmark in the health sector indicators: 'The health sector indicators all refer to health-related issues that various partners ranging from $\mathrm{MOH}$, district health authorities, hospitals, UN agencies, NGOs and community partners have a mandate to ensure' (WHO: South-east Asia 2020).

To measure the Covid-19 pandemic as a health emergency that threatens life, it must meet the benchmark and indicator in health emergency terms. However, because the indicators have to serve different countries, it is up to each country to formulate appropriate and measurable indicators that fit the situation. In order to categorise a country in health emergency terms, it must meet at least four of the benchmark and indicators (WHO: South-east Asia 2020). The benchmark and indicator of considerations in Table 1.

The table uses twelve benchmarks and indicators of health emergency measures to show whether Indonesia is in a health emergency that threatens the nation's life. Overall, it proves that the health emergency meets nine out of 12 benchmarks and indicators showing that Indonesia is in a health emergency regardless of an informal legal framework, dubious data from the Minister of Health, and its inability to identify risks and assess vulnerability in communities. Also, the WHO categorised the Covid-19 outbreak as a PHEIC, and gives urgent order to President Jokowi Widodo to declare a national emergency proves that the country is in a health emergency. The spreading of Covid-19, which is dangerous for the country's life with the ratio between those affected and a high mortality rate of $8.1 \%$ (Rodriguez 2020), proves the crisis qualifies as a threat to the nation. This can be compared to Vietnam's policy that further limited the right to move but showed the most convincing evidence of zero deaths (Worldometer 2020).

Though Indonesia meets several health emergency measures, it lacks the minimum need for essential health services and supplies at the local level. It also lacks the capacity to identify risks and assess vulnerability that has been established in communities (Jaffrey 2020). However, it is suggested that Indonesia meet the requirements for an emergency regardless of the minimum needs for essential health services and supplies at the local level and the capacity to identify risks and assess vulnerabilities as essential conditions to help individuals and healthcare workers to take appropriate action to slow the spread of the virus (Sparrow et al. 2020).

\section{Prescribed by Law}

The 'prescribed by law' element means that the state can limit individual human rights as long as it is based on the Act (Undang-Undang). In other words, the state is not allowed to restrict human rights based on legal products that are hierarchically under the Act. Also, the point prescribed by law expressly states the validity of the principle of nonretroactivity in each application (Woodhouse 1955).

Rules regarding lockdown do not exist in Indonesian legal provisions. All emergency situation or national disaster status determination refers to Law (UU) Number 24 of 2007 concerning Disaster Management. However, this law does not recognise the concept of social distancing (Setiawan 


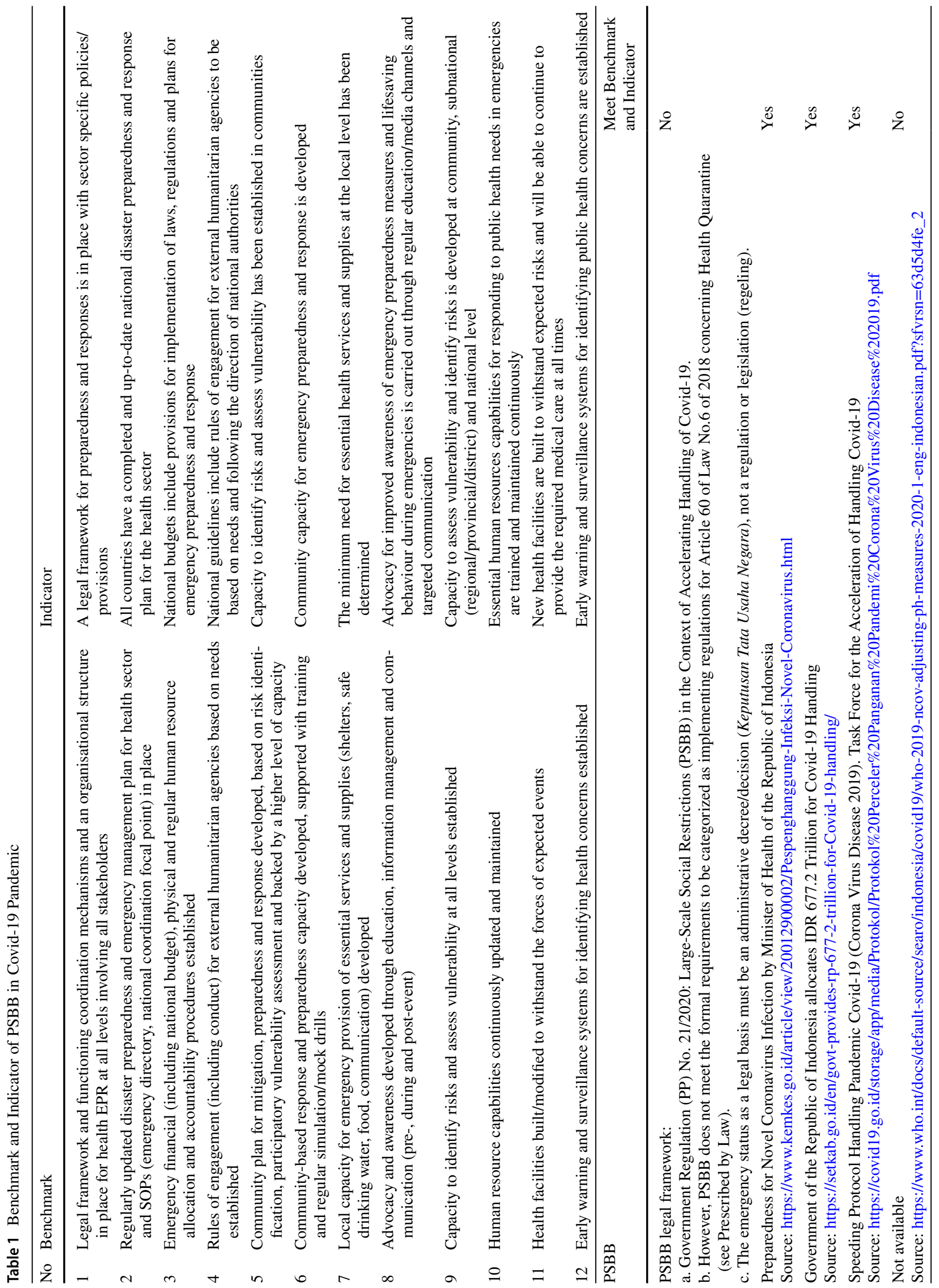


2020). If what is meant by social distancing is 'social restrictions' or PSBB, it is known only in Law Number 6 of 2018 concerning Health Quarantine. Article 59 of Law 6/2018 states that 'Large-Scale Social Restrictions (PSBB) are part of a Public Health Emergency'.

Based on Law Number 6 of 2018, regional quarantine is a restriction on the population in an area, including the area of entry and its contents that are suspected of being infected with a disease and/or contaminated in such a way as to prevent the possibility of spreading disease or contamination. Apart from regional quarantine, the term large-scale social restriction is the limitation of certain activities of residents in an area suspected of being infected with a disease and/or contamination in such a way as to prevent the possibility of spreading infectious diseases. Social distancing is only an appeal to individuals and is not required in the workplace/company.

Formally the PSBB does not meet the requirements to be categorized as implementing regulations for Article 60 of Law No.6 of 2018 concerning Health Quarantine. First, the PSBB title is specific to the acceleration of the handling of Covid-19. While the delegation from Article 60 of Law $6 / 2018$ is general in nature for any situation and at any time that has been designated as a Public Health Emergency.

Second, in the consideration of deciding not to mention that PSBB was formed as an implementation / delegation of Article 60 of Law 6/2018. The PSBB should state the basis for the consideration of the formation of implementing regulations from a law. Moreover, this PP is a delegation of certain laws, which are regulated in the attachment to Law Number 12 of 2011 concerning the Formation of Legislative Regulations.

Third, the content of PSBB turns out to only include the criteria/conditions and implementation of the PSBB. In fact, Article 60 of Law 6/2018 states that what is further regulated is not only large-scale social restrictions, but also the criteria and implementation of house, area and hospital quarantine.

Fourth, the emergency status as a legal basis must be an administrative decree/decision (KTUN/Keputusan Tata Usaha Negara), not a regulation or legislation such as Government Regulation No. 21/2020 (Wiratman 2020).

Therefore, PSBB Regulation has not yet fully regulated the technical aspects of implementing PSBB. It does not meet 'Legal rules limiting the exercise of human rights shall be clear and accessible to everyone' requirement (Limitation Clauses, point 17). Thus, it is enough to prove this regulation does not meet the element 'prescribed by law' of Siracusa Principles.

\section{Based on Scientific Evidence and Not Arbitrary or Discriminatory in Application}

Regarding scientific evidence, Brownson (2003) argue that all scientific evidence is imperfect. However, the absence of extraordinary evidence does not make evidence-based decision-making impossible. It must use 
the best evidence that is possible (Brownson et al. 2003). In the context of a pandemic, the rationale of regulation must also read (Brownson 2003). If the rationale of the regulation is evidence-based government data, it could be inaccurate. One of the grounds of PSBB in its consideration stipulates that:

'the spread of Coronavirus Disease 2019 (Covid-19) with the number of cases and the number of deaths has increased and spreads across regions and countries and has an impact on political, economic, social, cultural, defence and security aspects as well as the welfare of the people in Indonesia'. (Minister of Health Regulation No. 9 of 2020 Concerning PSBB).

A recent national survey conducted by Charta Politica (2020) regarding the Government's openness in handling Covid-19 shows that $40.9 \%$ of respondents do not believe the Covid-19 data from the Government. Moreover, 31.9\% of respondents stated that the Government is not open about Covid-19 and $32.3 \%$ of respondents stated that the handling of the pandemic did not follow expert advice.

The Indonesian government has to solve several cases related to the Covid-19 data's inconsistency. The number of deaths that have increased in all regions and countries has no validity because the Government's data is inaccurate (Bernie 2020). The Indonesian Government not only failed to provide transparent data but might even have actively misinformed its citizens. These actions further escalate the damage caused by Covid-19 in Indonesia (Oleh and Daraini 2020).

The regulations are also discriminatory towards certain people. The PSBB Regulation officers were only strict with one group of the population, while they were relaxed towards certain groups. For example, the Government also allowed business people to use aeroplanes, whereas previously, it was only permitted to transport goods (Kompas 2020). The local government did not provide a quick response if there were problems in an area, such as discrimination in the form of rejection of victims or medical personnel who treated Covid-19 patients (Habibie 2020). Discrimination occurred regarding the funerals and the burial of the corpses of Covid-19 victims by villagers in some areas in Indonesia and isolation from neighbours despite negative examination results (Manajemen Rumah Sakit 2020).

Based on the above, the PSBB Regulation does not meet 'Based on scientific evidence and not arbitrary or discriminatory in application' requirement of Siracusa Principles.

\section{Limited Duration, Respect for Human Dignity and can be reviewed}

The PSBB Regulation came into force during the most extended incubation period: that is, 14 days. If new cases were reported, it remained applicable within 14 days of the last case's discovery. The results of the evaluation of the implementation of the PSBB within the specified period showed failure. Some cities such as Jakarta, Bogor, Depok, Tangerang and Bekasi were threatened due to failure to obey the rules. Until the PSBB Regulation period ended, it turned out that positive Covid-19 case numbers were still growing. As of 12 June 2020, there were 979 new cases, resulting in the total number of people infected with Covid-19 to that date reaching 35,295 (Kompas 12 June 2020). According to the Economic and Financial Developments (INDEF), the Covid-19 pandemic policy in Indonesia was at least successful or worse than the success rates of neighbouring ASEAN countries.

After a failure to enforce the PSBB Regulation for three months, the Government of Indonesia shifts to the new normal period, which means that people enter 'herd immunity' or those immune to Covid-19 will survive. Those who are not immune will die (Mariska, 2020). The new normal is not clearly defined in how people applying health protocols are better prepared to return to active and productive activities. Consequently, the death rate from Covid-19 continues to increase until it reaches a thousand deaths a day (Fadill 2020).

The government had carried out the PSBB extension many times since it took effect in March 2020. Especially in Java and Bali, the PSBB extension was from 11 to 25 January 2021, and there has been no official extension information. (Ministry of Communication and Informatics 2020), shows that this policy does not fulfill limited duration elements.

\section{Conclusions}

Large-Scale Social Restriction-PSBB is Indonesia's policy to save human lives from the health crisis due to the spread of Covid-19. This rule limits the freedom of movement, including the prohibition of moving from one place to another. The state's intention in implementing the PSBB was to save human lives from Covid-19. PSBB appears to be a pro-poor policy, but it is a disaster for humanity. This results from the ineffective implementation of PSBB, increased unemployment rates, uncertain future of schoolchildren, prolonged economic recession, increased mortality and stigma and 
discrimination experienced by ordinary people and healthcare workers both during treatment and until burial.

The PSBB is a misguided policy and cannot be implemented in Indonesia if it does not meet the population's basic needs. The PSBB does not fulfil the elements of limiting rights stipulated in international human rights law, particularly the scientific evidence, the prescribed by law, non-arbitrary and discriminatory, and the limited duration, respect for human dignity elements. Exceptional measures taken by the government due to health emergency seems illegal, unnecessary, violate human rights especially rights to life and health.

Thus, a government must be consistent in mitigating and preventing the Covid-19 pandemic outbreak by referring to the Health Quarantine Act of 2018 which is based on reliable or scientific evidence. The Central and Local governments are obliged to fulfil the mandates of the Health Quarantine Act of 2018 and the Infectious Disease Act of 1984, specifically in fulfilling citizens' fundamental rights following international standards for a decent living. The Government of Indonesia should stop all legal acrobatic efforts and flawed application of the law by manoeuvring the discourse of enacting the status of 'Public Emergency Threatening the Nation's Life,' which seeks to avoid the state's responsibility towards its people. To realise the effective and conducive handling of the Covid-19 outbreak and fulfilment of fundamental rights, the PSBB Regulation must meet emergency measures and the elements stipulated by the Siracusa Principles to avoid misery on humanity.

Acknowledgements The author would like to thank to the Faculty of Law, Christian University of Indonesia for generous support during this research.

\section{References}

Abiola, S. (2011). The Siracusa Principles on the Limitation and Derogation Provisions in the International Covenant for Civil and Political Rights (ICCPR): History and Interpretation in Public Health Context. Siracusa Principles Memo Prepared for Open Society Institute Law and Health Initiative. Harvard University. http://health-rights.org/index.php/cop/item/memo-the-siracusaprinciples-on-the-limitation-and-derogation-provisions-inthe-international-covenant-for-civil-and-political-rights-iccprhistory-and-interpretation-in-public-health-context

Allard, T., Widianto, S. (2020). Indonesia's Health System on the brink as Coronavirus surge looms. Reuters, March 25. https://www.reuters.com/ article/us-health-coronavirus-indonesia-response-idUSKBN21C0J6

Amadasun, S. (2020). Social work and Covid-19 pandemic: An action call. International Social Work, 63(6), 753-756. https://doi.org/10. $1177 / 0020872820959357$.

American Association for the International Commission of Jurists (ICJ). (1984, 1 July). Siracusa principles on the limitation and derogation provisions in the international covenant on civil and political rights. https://www.icj.org/wp-content/uploads/1984/07/ Siracusa-principles-ICCPR-legal-submission-1985-eng.pdf
Amnesty International. (2020, 13 July). Global report: Health workers left exposed, silenced and assaulted. https://www.amnesty.org/en/ latest/news/2020/07/health-workers-rights-covid-report/

Andriani, H. (2020). Effectiveness of large-scale social restrictions (PSBB)toward the new normal era during Covid-19 outbreak: A mini policy review. Indonesian Journal of Health Policy and Administration, 5(2): 61-65. https://orcid.org/0000-0001-5057-0851

Antara. (2020, 28 July). Mabes Polri Catat 102 Kasus Dugaan Penyelewengan Bansos Covid-19 [National Police Headquarters records 102 alleged cases of Covid-19 social assistance abuse]. Tempo. https://nasional.tempo.co/read/1369886/mabes-polri-catat102-kasus-dugaan-penyelewengan-bansos-Covid-19/full\&view=ok

Asia Pacific Foundation of Canada. (2020). Canada's View on Asia. https://www.asiapacific.ca/sites/default/files/publication-pdf/ 2020\%20NOP\%20Canadian\%20Views\%20on\%20Asia.pdf

Badan Pusat Statistik. (2020). BPS: The Poor Population in Indonesia Has Increased by 2.76 Million as A Result of The Covid-19 Pandemic. https://voi.id/en/berita/33154/bps-penduduk-miskin-di-indon esia-bertambah-2-76-juta-orang-imbas-dari-pandemi-Covid-19

Bernie, M. (2020, 7 April). Bahaya di Balik Dugaan Manipulasi Data Corona Covid-19 [The dangers behind suspected Corona Covid-19 data manipulation]. Tirto. https://tirto.id/eL1C

Brinkerhoff, S. (2014). Careers with character: Social worker. Mason Crest. https://www.simonandschuster.com/books/Social-Worker/ Shirley-Brinkerhoff/Careers-With-Character/9781422290620

British Association of Social Workers (BASW). (2020). The role of social workers in a pandemic and its aftermath: learning from Covid-19. https://www.basw.co.uk/role-social-workers-pandemicand-its-aftermath-learning-Covid-19

Brownson, R. C. (2003). Evidence-Based Public Health. Oxford University Press.

Business Insider. (2020, 20 March). A running list of countries that are on lockdown because of the coronavirus pandemic. https:// www.businessinsider.sg/countries-on-lockdown-coronavirusitaly-2020-3? $\mathrm{r}=\mathrm{US} \& \mathrm{IR}=\mathrm{T}$

Cabinet Secretariat of the Republic Indonesia. (2020). Government Declares Covid-19 Pandemic as National Disaster. https://setkab. go.id/en/govt-declares-Covid-19-pandemic-as-national-disaster/

Central Statistic Agency. (2020). BPS: The Poor Population in Indonesia Has Increased by 2.76 Million as A Result of The COVID19 Pandemic. https://voi.id/en/berita/33154/bps-pendudukmiskin-di-indonesia-bertambah-2-76-juta-orang-imbas-daripandemi-covid-19

Charta Politica. (2020, 22 July). Rilis Survei Nasional "Trend 3 Bulan Kondisi Politik, Ekonomi dan Hukum Pada Masa Pandemi Covid19" [3 Month Trend of Political, Legal and Economy Condition During the Covid-19 Pandemic. National Survey]. 6-12 July. http://www.chartapolitika.com/wp-content/uploads/2020/07/ 20200722_Report_Phone-Survei-FINAL.pdf

Christoffersen, J. (2009). Fair balance: Proportionality, subsidiarity, and primarity in the European convention on human rights. International Studies on Human Rights Vol. 99. Martinus Nijhoff.

CNN Indonesia (2020, 5 December). WHO: Angka Kematian Covid RI 3,4\%, Data Tak Penuhi Standar [WHO: The RI Covid Death Rate is 3.4\%, Data Does Not Meet Standards]. https://www.cnnindonesia. com/nasional/20201204141420-20-578011/who-angka-kematiancovid-ri-34-data-tak-penuhi-standar

Disantara, F. P. (2020). The Large Scale Social Restrictions Policy for handling the Covid-19 Pandemic. Jurnal Pembaharuan Hukum, $7(2), 128-141$.

Djalante, R., Lassa, J., Setiamarga, D. Sudjatma, A. Indrawan, M. Haryanto, B., Mahfud, C. , Sinapoy, M. S., Djalante, S., Rafliana, I., Gunawan, L. A., Surtiari, G. A. K., Warsilah, H. (2020). Review and analysis of current responses to Covid-19 in Indonesia: Period of January to March 2020. Progress in Disaster Science. 6 (Apr 2020). https://doi. org/10.1016/j.pdisas.2020.100091 
Dwi, R. (2020, May 22). Mengevaluasi Penanggulangan COVID-19 [Evaluating the Countermeasures for COVID-19]. Balairung Press. https://www.balairungpress.com/2020/05/mengevaluasipenanggulangan-covid-19/

Fadill, I. (2020, June 11). New Normal di Saat Pandemi Covid-19 Semakin Memburuk [New Normal at a time when the Covid-19 Pandemic was getting worse]. Merdeka. https://www.merdeka.com/ dunia/new-normal-di-saat-pandemi-Covid-19-semakin-memburuk. html

Firdaus, F. \& Racthliffe, R. (2020, 12 July). Indonesia is failing to control coronavirus outbreak, say experts. The Guardian. https:// www.theguardian.com/world/2020/jul/12/indonesia-is-failing-tocontrol-coronavirus-outbreak-warn-experts-testing-governmentmessages-bogus-cures

Government Regulation No. 21. (2020). Concerning Large-Scale Social Restrictions in Order to Accelerate Handling of Corona Virus Disease 2019 (COVID-19). https://jdih.setneg.go.id/Produk

Habibie, N. (2020, April 27). Pengamat: PSBB Tak Efektif, Harus Pertegas Sanksi, Kuatkan Peran RT [Observer: PSBB is Not Effective, Must Be Affirmed Sanctions Strengthen the Role of Households]. Merdeka. https://www.merdeka.com/jakarta/pengamat-psbb-takefektif-harus-pertegas-sanksi-kuatkan-peran-rt.html

Huscroft, G., Miller, B.W. \& Webber. G. (Eds.). (2014). Proportionality and the Rule of Law: Rights, Justification, Reasoning, Cambridge University Press. https://doi.org/10.1017/ CBO9781107565272

Indonesian Institute of Sciences (LIPI). (2020 June). 15, 6 per cent of Workers/Employees who were laid off due to Corona and 3.8 per cent did not receive severance pay. http://kependudukan.lipi.go. $\mathrm{id} / \mathrm{id} /$ berita/liputan-media/955-lipi-15-persen-buruh-terkena-phkkarena-corona-dan-3-8-persen-tak-terima-pesangon

Intan, G. (2020, April 29). Data Pemerintah Soal Korban Tewas Akibat Corona Dipertanyakan [Government Data Regarding Death toll from Corona Questioned]. VOA Indonesia. https://www. voaindonesia.com/a/data-pemerintah-soal-korban-tewas-akibatcorona-dipertanyakan/5397363.html

Ivanka, M. (2020). Large-Scale Social Restrictions: What is next? The Indonesian Journal of International Clinical Legal Education, 2(2), 201-214. https://doi.org/10.15294/ijicle.v2i2.38324

Jaffrey, S. (2020, 29 April). Coronavirus Blunders in Indonesia Turn Crisis into Catastrophe. Carnegie Endowment for International Peace. https://carnegieendowment.org/2020/04/29/coronavirus-blunders-inindonesia-turn-crisis-into-catastrophe-pub-81684

John Hopkins Bloomberg School of Public Health. (2020). Covid-19 School of Public Health Expert Insight. COVideo19: Bloomberg School Translate the Science in Bahasa Indonesia. https://www. globalhealthnow.org/2020-04/covideo19-bloomberg-schooltranslate-science-bahasa-indonesia.

Klatt, M., \& Meister, M. (2012). The Constitutional Structure of Proportionality. Oxford University Press.

Kompas. (2020, 27 April). Ini Klarifikasi Kemenhub soal Pebisnis yang Boleh Naik Pesawat [This is the Ministry of Transportation's clarification regarding business people who are allowed to ride planes]. Kompas. https://money.kompas.com/read/2020/04/ 27/211559526/ini-klarifikasi-kemenhub-soal-pebisnisyang-bolehnaik-pesawat

Leavy, P. (2011). Essentials of Transdisciplinary Research Using Problem-Centered Methodologies. Routledge.

Luwis, S. (2008). Eradication of Pes Disease in Malang, 1911-1916. Thesis. Jakarta: The University of Indonesia.

Mabillard, V., \& Pasquier, M. (2015). Transparency and trust in government: A two-way relationship. Yearbook of Swiss Administrative Sciences, 6(1), 23. https://doi.org/10.5334/ssas.78.

Mahmud, A., Imaniyati, N., Neni, S., \& Husaeni Uus, A. (2020). Large scale social restriction policy in overcoming Corona Virus Disease 19: Social and economic problems. International Journal of
Psychosocial Rehabilitation, 24(8), 4797-4808. https://doi.org/10. 37200/IJPR/V24I8/PR280495.

Manajemen Rumah Sakit. (2020, April 21). Stigma, Diskriminasi di Masyarakat dan Mereka yang Bertaruh Nyawa di Garda Depan [Stigma, Discrimination in the Community and Those Who Bet Their Lives on the Front Guard]. https://manajemenrumahsakit. net/2020/04/stigma-diskriminasi-di-masyarakat-dan-merekayang-bertaruh-nyawa-di-garda-depan/

Marchelin, T. (2020, 2 April). Indonesia needs more and better health facilities to counter Coronavirus epidemic: Ombudsman. Jakarta Globe. https://jakartaglobe.id/news/indonesia-needs-moreand-better-health-facilities-to-counter-coronavirus-epidemicombudsman/

Mariska, D. (2020, 3 June). Indonesian Gov't Denies Turning to Herd Immunity. JakartaGlobe. https://jakartaglobe.id/news/indonesiangovt-denies-turning-to-herd-immunity

Ministry of Communication and Informatics. (2020). KI Keluarkan Pedoman Keterbukaan Informasi Saat Pandemi [K.I. Issues Guidelines for Information Disclosure During Pandemic]. https://www.kominfo.go.id/content/detail/25619/ki-keluarkanpedoman-keterbukaan-informasi-saat-pandemi/0/berita_satker

Ministry of Finance of the Republic of Indonesia. (2020a, May 10). Perkembangan Ekonomi dan Refocusing Anggaran untuk Penanganan Covid-19 di Indonesia [Economic Development and Budget Refocusing for Covid-19 Handling in Indonesia]. https://www.kemenkeu.go.id/publikasi/siaran-pers/siaran-persperkembangan-ekonomi-dan-refocusing-anggaran-untukpenanganan-Covid-19-di-indonesia/

Ministry of Finance of the Republic of Indonesia. (2020b). The Impact of Covid-19, Economic Growth in the 2nd Quarter is Estimated to be Negative. https://www.kemenkeu.go.id/publikasi/berita/dampakCovid-19-pertumbuh-ekonomi-kuartal-2-diperangka-negatif/

Ministry of Foreign Affairs of the Republic of Indonesia (2019). Indonesia dan hak Asasi Manusia [Indonesia and Human Rights]. https://kemlu.go.id/portal/id/read/40/halaman_list_ lainnya/indonesia-dan-hak-asasi-manusia

Oleh, D. \& Daraini, I. N. (2020). Data transparency and misinformation of Covid-19 in Indonesia. Politik Nasional. http://www. politik.lipi.go.id/kolom/kolom-2/politik-nasional/1365-datatransparency-and-misinformation-of-Covid-19-in-indonesia

Osiatynski, W. (2009). Human rights and their limits. Cambridge University Press.

Parekh, P. H. (2009). Human rights year book. Universal Law Publishing Co.

Pramudiarja, A.U. (2020, February 15). Indonesia 'Kebal' Corona Covid-19, Menkes: Semua karena Doa!. [Indonesia is 'immune' to Corona COVID-19, Minister of Health: All because of Prayer!]. detikHealth. https://health.detik.com/berita-detikhealth/d-4900600/ indonesia-kebal-corona-Covid-19-menkes-semua-karena-doa? $\mathrm{ga}=2.223593624$.2029617959.1599809843-1014718815. 1598106641

Pujianto, E. (2020). Mitos Indonesia Kebal Corona Terbantahkan [The myth that Indonesia is immune to Coronavirus is refuted]. Indonesiainside, March 3. https://indonesiainside.id/news/nasional/ 2020/03/03/mitos-indonesia-kebal-corona-terbantahkan

Rodriguez, D. (2020). Indonesia Pays a Price for Tardy Response to Covid19. Asia Pacific Foundation of Canada. https://www.asiapacific.ca/ publication/indonesia-pays-price-tardy-response-Covid-19

Rosenfeld, M. \& Sajó, A. (Ed.). (2012). The Oxford Handbook of Comparative Constitutional Law, Oxford University Press.

Setiawan, R. (2020). Social Distancing Dinilai Tak Dikenal di Sistem Hukum Indonesia [Social Distancing is Considered Unknown in the Indonesian Legal System]. Tirto. https://tirto.id/social-distancingdinilai-tak-dikenal-di-sistem-hukum-indonesia-eFJ5

Singh, Y. K. (2006). Fundamental research methodology and statistics. (P. New Age International (P) Ltd., Ed.). New Delhi. 
Smith, Rhona, K.M. (2012). Textbook on International Human Rights 5th Edition, New York: Oxford University Press Inc.

Solahuddin, G. (2020, 19 July). 3.000 Tenaga medis meninggal dunia terinfeksi Covid-19 selama pandemi Covid-19 [3,000 medical personnel died infected with Covid-19 during the Covid-19 Pandemic]. Gridhealth. https://health.grid.id/read/352244856/3000-tenaga-medismeninggal-dunia-terinfeksi-Covid-19-selama-pandemi-Covid-19? page $=$ all

Sparrow, R., Dartanto, T., \& Hartwig, R. (2020). Indonesia under the new normal: Challenges and the way ahead. Bulletin of Indonesian Academic Studies, 56(3), 269-299. https://doi.org/10.1080/00074918. 2020.1854079

Sulistyawati, L. (2020, 1 April). Istana Ungkap Alasan Presiden Pilih PSBB Dibanding Lockdown [Istana Reveals the President's Reasons for Choosing PSBB instead of Lockdown]. Republika. https://republika. co.id/berita/q83nhv354/istana-ungkap-alasan-presiden-pilih-psbbdibandingem-lockdownem

Sun, N. (2020). Applying Siracusa: A call for a general Comment on Public Health Emergencies. Health and Human Rights Journal, 22(1), 387-390.

Suraya, I., Nurmansyah, M. I., Rachmawati, E., Al Aufa, B., \& Koire, I. K. (2020). The impact of large-scale social restrictions on the incidence of Covid-19: A case study in four provinces in Indonesia. Kesmas Jurnal Kesehatan Masyarakat Nasional (National Public Health Journal). Special Issue, 1, 49-53. https://doi.org/10.21109/kesmas.v15i2.3990.

Suryahadi, A., Al Izzati, R. \& Suryadharma, D. (2020, April). The impact of Covid-19 outbreak on poverty: An estimation for Indonesia, Working Papers (Draft), The SMERU Research Institute. https://www.smeru.or.id/sites/default/files/publication/ wp_covid19impact_draft.pdf

Syafri, H., Sangadji, E. \& Utami, Rade, R.M. (2020). Impact analysis of the large-scale social restrictions (PSBB) policy implementation in Jakarta. Journal of Indonesian Health Policy and Administration, 5(2): 61-65. https://journal.fkm.ui.ac.id/ihpa/article/view/4056/0

Tarigan, E. \& Milko, V. (2020, 9 September). As Indonesia cases soar, medical workers bear the burden. ABC News. https://abcnews.go. $\mathrm{com} / \mathrm{Health} /$ wireStory/indonesia-cases-soar-medical-workers-bearburden-72894789

The Jakarta Post. (2020a). Jokowi declares Covid-19 'national disaster', gives task force broader authority. https://www.thejakartapost. com/news/2020/04/14/jokowi-declares-Covid-19-national-disastergives-task-force-broader-authority.html

The Jakarta Post. (2020b). Covid-19: WHO urges Jokowi to declare a national emergency News Desk. https://www.thejakartapost.com/ news/2020/03/14/Covid-19-who-urges-jokowi-to-declare-nationalemergency.html.

The Jakarta Post. (2020c). What went wrong in Indonesia's Covid-19 responses and what can be done. https://www.thejakartapost.com/ academia/2020/12/03/insight-nine-months-and-no-progress-whatwent-wrong-in-indonesias-Covid-19-responses-and-what-can-bedone.html

The World Bank. (2020). Indonesia Economic Prospect: The Long Road to Recovery. https://www.worldbank.org/en/country/indonesia/ publication/july-2020-indonesia-economic-prospect
Transparency International Indonesia Report. (2020). Tidak Transparan ke Publik, Anggaran Covid-19 Rawan Disalahgunakan. [Not Transparent to the Public. The COVID-19 Budget is Prone to Misuse]. https://ti.or.id/tidak-transparan-ke-publik-anggaran-Covid-19rawan-disalahgunakan/

United Nations. (2020). Covid-19 and human rights: we are all in this together. https://unsdg.un.org/sites/default/files/2020-04/ Covid-19-and-Human-Rights.pdf

United Nations Commission on Human Rights. (1984). The Siracusa Principles on the Limitation and Derogation Provisions in the International Covenant on Civil and Political Rights, 28 September, 1984, E/CN.4/1985/4. https://www.icj.org/wp-content/uploads/ 1984/07/Siracusa-principles-ICCPR-legal-submission-1985-eng. pdf

United Nations Human Rights Office of the High Commissioner (OHCHR). (2020). Emergency Measures and Covid-19: Guidance. https://www. ohchr.org/Documents/Events/EmergencyMeasures_COVID19.pdf

UNICEF. (2020, May). Covid-19 and Children in Indonesia: An Agenda for Action to Address Socio-Economic Challenges. https://www. unicef.org/indonesia/sites/unicef.org.indonesia/files/2020-05/ Covid-19-and-Children-in-Indonesia-2020_0.pdf

Webber, G. (2009). The negotiable Constitution: On the limitation of rights. Cambridge University Press.

Wiratraman, H. P. (2020). Does Indonesian Covid-19 Emergency Law Secure Rule of Law and Human Rights. Journal of Southeast Asian Human Rights, 4(1), 306-334. https://doi.org/10.19184/jseahr.v4i1. 18244.

Woodhouse, J. T. (1955). The principle of retroactivity in international law. Transactions of the Grotius Society, 41, 69-89. http://www. jstor.org/stable/743291

World Health Organization. (2020a). COVID 19 Public Health Emergency of International Concern (PHEIC) Global research and innovation forum: towards a research roadmap.12 February 2020. https://www.who.int/publications/m/item/Covid-19-public-healthemergency-of-international-concern-(pheic)-global-research-andinnovation-forum

World Health Organization. (2020b). Health Emergency Dashboard, Vietnam. https://covid19.who.int/region/wpro/country/vn

World Health Organization. (2020c). Coronavirus Disease 2019 (COVID-19) Situation Report-4. 16 April 2020. https://www.who. int/docs/default-source/searo/indonesia/covid19/who-situationreport-4-16april2020.pdf?sfvrsn=16a32d2a_2

World Health Organization Indonesia. (2020a). Coronavirus Disease 2019 (COVID-19) Situation Report-13. https://www.who.int/docs/ default-source/searo/indonesia/covid19/external-situation-report13-25june2020.pdf?sfvrsn=40029af0_6

World Health Organization Indonesia. (2021b). Coronavirus Disease 2019 (COVID-19) Situation Report, 56. 26 May 2021. https://cdn.who.int/ media/docs/default-source/searo/indonesia/covid19/external-situationreport-56_26-may-2021.pdf?sfvrsn=b05d7bb5_5

World Health Organization: South-East Asia. (2020). Benchmarks, Standards and Indicators for Emergency Preparedness and Response. http://origin.searo.who.int/entity/emergencies/ehabenchmarks.pdf

Worldometer. (2020, May 27). Covid-19 coronavirus pandemic: Coronavirus Cases. https://www.worldometers.info/coronavirus/ 